Available online at: http://journal.unj.ac.id

Jurnal

Pensil

Pendidikan Teknik Sipil

Journal homepage: http://journal.unj.ac.id/unj/index.php/ipensil/index

\title{
RELEVANSI MATA KULIAH ILMU BAHAN BANGUNAN TERHADAP BAHAN BANGUNAN DI DUNIA INDUSTRI
}

\section{RELEVANCE OF BUILDING MATERIALS SCIENCE COURSES TO BUILDING MATERIALS IN THE INDUSTRIAL WORLD}

\author{
Anestasya Ayunda', Kusno Adi Sambowo ${ }^{2}$ \\ ${ }^{1,2}$ Universitas Negeri Jakarta \\ ${ }^{1}$ AnestasyaAyunda_5415160266@mhs.unj.ac.id, ${ }^{2}$ kusnoadisambowo@unj.ac.id
}

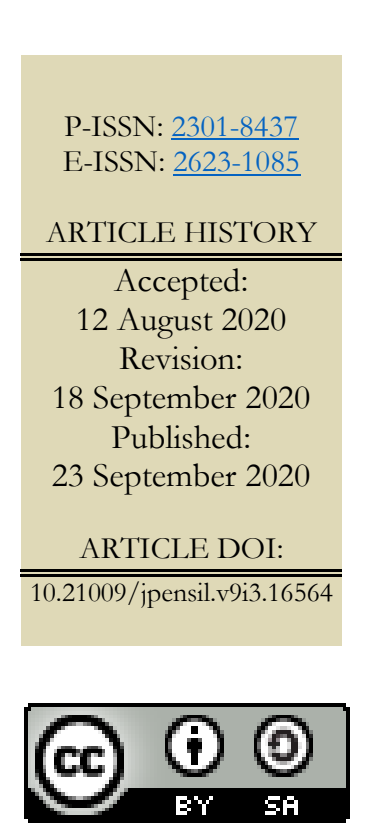

Jurnal Pensil :

Pendidikan Teknik

Sipil is licensed under a

Creative Commons

Attribution-ShareAlike

4.0 International License

(CC BY-SA 4.0).

\begin{abstract}
Abstrak
Penelitian ini bertujuan untuk meningkatkan nilai dan keterampilan siswa pada mata pelajaran Aplikasi Perangkat Lunak dan Desain Interior Gedung. Pelaksanaan penelitian tindakan kelas ini terdiri dari dua siklus (siklus I dan siklus II) dengan setiap siklus dilakukan dua kali pertemuan. Siswa melaksanakan pembelajaran berbasis proyek; Artinya, siswa langsung berlatih menggambar dengan lembar kerja yang disediakan. Peran tutor sebaya disini adalah membantu guru dalam membimbing siswa dalam menyelesaikan proyek, didampingi dan diarahkan oleh guru. Hasil yang diperoleh menunjukkan bahwa pada siklus I aspek keaktifan siswa mencapai rata-rata 76\% (Cukup Aktif) dan ketercapaian nilai pengetahuan $17,1 \%$ siswa berkompeten. Sebagai perbandingan, pencapaian skor keterampilan adalah 25,7\% siswa berkompeten dengan KKM (Kriteria Ketuntasan Maksimal) 76. Pada siklus II terjadi peningkatan yang signifikan dengan keaktifan siswa meningkat menjadi rata-rata $86 \%$ (Aktif), sedangkan pencapaian skor pengetahuan meningkat menjadi $91,43 \%$ siswa berkompeten dan pencapaian skor keterampilan juga meningkat dari segi ketuntasan belajar yaitu menjadi 94\% siswa berkompeten.
\end{abstract}

Kata kunci: Peningkatan Kompetensi, Tutor Sebaya, Project Based Learning Abstract
In the current era of the development of the infrastructure industry, the building
material industry in Indonesia has developed very rapidly along with the increasing
national economic conditions and innovative technological advancements. In
connection with this progress, resulting in increasing needed human resources,
especially students who are able to have the knowledge, competencies, and expertise
in accordance with the progress and development of the building materials industry.
Given the demands and encouragement from the industrial world, the Building
Material Science Course is expected to be a means to shape these competencies by
looking at the relevance of the development of innovative building materials, so that
graduates are expected to produce students who have up-to-date knowledge and 
competencies related to materials building in the industrial world. The purpose of this article is to increase knowledge and information related to the development of building materials, especially buildings in the industrial world, through the study of Building Materials Science. The method used is the literature review. Literature study results show that learning from lectures is able to contribute to the increase in knowledge and competencies related to the development of building materials that are relevant to the industrial world, one of which is the Building Materials Science Course. The more competence of students regarding building materials, the building in any form can be easily realized when working in the industrial world.

Keywords: Relevance, Building Materials, Infrastructure, Industry

\section{Pendahuluan}

Di era perkembangan industri, pembangunan infrastruktur yang sangat pesat adalah pembangunan gedung, baik itu tempat tinggal, perkantoran, ataupun industri lainnya. Berkaitan dengan adanya kemajuan tersebut, manusia memerlukan ilmu yang berkaitan dengan bangunan atau sesuatu yang dapat menunjang dalam membuat suatu bangunan. Salah satunya adalah bahan bangunan. Bahan bangunan adalah material atau bahan yang digunakan dalam pelaksanaan pembangunan proyek, yang persyaratan mutunya harus sesuai dengan dokumen kontrak.

Industri bahan bangunan di Indonesia berkembang dengan sangat cepat. Hampir di seluruh dunia industri khususnya yaitu proyek pembangunan gedung, telah menggunakan bahan bangunan modern sebagai penunjang bangunanya. Salah satunya bahan bangunan yang terbaru dan inovatif untuk industri proyek adalah wood concrete. Wood concrete atau beton dari kayu merupakan inovasi lanjut dalam bidang produksi beton, dimana dalam pembuatannya menggunakan 50 persen kayu dan merupakan inovasi bahan bangunan komposit yang dapat digunakan untuk pembangunan perumahan dan gedung perkantoran. Selain itu ada pula seperti carbon concrete, yaitu beton yang dikombinasikan dengan serat karbon dan memiliki kekuatan yang lebih kuat daripada beton konvensional.

Mahasiswa saat ini belum sepenuhnya mengetahui kenyataan bahwa ilmu bahan bangunan yang biasa digunakan telah berkembang. Kemajuan inilah yang menyebabkan kemungkinan adanya ketertinggalan terkait pemahaman mahasiswa mengenai bahan bangunan yang berkembang dan mulai digunakan pada proyek pembangunan khususnya bangunan gedung, maka Mata Kuliah Ilmu Bahan Bangunan perlu menjadi sarana untuk membentuk kompetensi terkait pemahaman tentang perkembangan bahan bangunan, sehingga diharapkan tujuan lulusannya dapat terwujud.

Mata kuliah Ilmu Bahan Bangunan merupakan mata kuliah yang mempelajari bahan-bahan bangunan yang biasa digunakan untuk proyek pembangunan. Pada materi pokok ajar pada Mata Kuliah Ilmu Bahan Bangunan memiliki topik yang menjadi bahasan yang akan dijelaskan kepada mahasiswa untuk setiap pertemuannya dengan menyesuaikan kurikulum yang ada antara lain, sifat-sifat fisika dan mekanik bahan bangunan dan pengujian, kayu sebagai bahan bangunan, produk turunan kayu, batu buatan (bata merah dan batako), bahan pengikat (semen, kapur dan aspal), baja dan logam sebagai bahan bangunan, agregat, batu buatan (beton dan produk turunannya), bahanbahan finishing (cat), dan bahan-bahan 
bangunan modern (baja ringan, kaca dan plastik).

Mengingat adanya tuntutan abad 21 kepada mahasiswa yang nantinya akan semakin saling berkompetensi dan dituntut menjadi sumber daya manusia yang berkembang dan inovatif di dunia industri, yang semakin up to date terhadap bahan bangunan terbaru, maka Mata Kuliah Ilmu Bahan Bangunan perlu dilakukan relevansi sesuai dengan perkembangan bahan bangunan dilapangan khususnya proyek bangunan gedung, dikarenakan sudah selayaknya di Perguruan Tinggi khususnya kompetensi Teknik Sipil dapat membekali mahasiswa dengan kemampuan terkait pemahaman bahan bangunan.

Berdasarkan uraian latar belakang tersebut, maka dilakukan penelitian dengan tentang "Relevansi Mata Kuliah Ilmu Bahan Bangunan Terhadap Bahan Bangunan di Dunia Industri". Tujuan dari penelitian ini adalah untuk mengetahui relevansi Mata Kuliah Ilmu Bahan Bangunan terhadap bahan bangunan di dunia industri.

Kajian Literatur

Relevansi

Relevansi memiliki arti yang berarti keterkaitan atau kecocokan. Menurut kamus bahasa Indonesia, relevansi yaitu bersangkut-paut, berguna secara langsung. Relevansi adalah kesatuan yang terdapat antara output pendidikan dengan tuntutan kebutuhan di lapangan. Relevansi memiliki konsep, yaitu memandang. Dengan kata lain, sebuah materi ataupun dokumen akan dianggap relevan jika telah memenuhi dan sesuai dengan tuntutan yang dibutuhkan (Novianto, Suherman, \& Ariyano, 2015). Menurut pendapat Hasbiyallah (2016), relevansi bersifat memudahkan dalam memecahkan masalah kebutuhan akan informasi dari suatu dokumen. Faktor utama yang termasuk dalam penilaian kesesuaian dokumen adalah topiknya, atau subjek yang diteliti.

Dalam pendidikan, relevansi memiliki prinsip yaitu mengembangkan kurikulum yang dimana dalam satuan pendidikan dijadikan sebuah pedoman dalam melaksanakan pembelajaran. Fungsi pengembangan kurikulum adalah agar kurikulum yang dijadikan pedoman terus selaras dengan perkembangan jaman. Prinsip relevansi ada dua, yaitu relevansi internal dan relevansi eksternal. Relevansi internal adalah relevansi antara kurikulum itu sendiri, terdapat konsistensi antar komponen kurikulum. Sedangkan relevansi eksternal adalah relevansi antara kurikulum dengan lingkungan hidup mahasiswa dan lingkungan di masyarakat, perkembangan tuntutan kehidupan dimasa saat ini dan akan datang, serta tuntutan akan dunia kerja (Hamdan, Suherman, \& Ariyano, 2015). Relevansi kurikulum diperlukan karna akan sangat membantu mahasiswa mengikuti tuntutan pekerjaan yang diinginkan, melatih dalam melaksanakan tugas, maupun kegiatan yang lain.

Dari beberapa pendapat yang telah tercantum di atas, maka dapat disimpulkan bahwa relevansi adalah keselarasan topik dari sebuah dokumen atau materi dengan mengikuti tuntutan kebutuhan yang ada di lapangan. Sedangkan relevansi pendidikan adalah keselarasan atau kesesuaian antara komponen kurikulum dengan kebutuhan di masyarakat dengan mengikuti perkembangan jaman.

\section{Mata Kuliah Ilmu Bahan Bangunan}

Mata Kuliah Ilmu Bahan Bangunan merupakan mata kuliah yang mempelajari bahan-bahan bangunan yang biasa digunakan untuk proyek pembangunan, khususnya adalah bangunan gedung. Tujuan mata kuliah ini adalah agar mahasiswa mampu memahami sifat-sifat dan karakteristik, pengolahan, cara pengujian dan evaluasi bahan bangunan. Outcome dari mata kuliah ini adalah, mahasiswa diharapkan mampu menjelaskan aplikasi macam-macam bahan bangunan di lapangan, dan memahami baik buruknya suatu bahan bangunan (Buku Pedoman Akademik Fakultas Teknik, 2017).

Pada materi pokok ajar pada Mata Kuliah Ilmu Bahan Bangunan memiliki 
topik yang menjadi bahasan yang akan dijelaskan kepada mahasiswa untuk setiap pertemuannya dengan menyesuaikan kurikulum yang ada antara lain, sifat-sifat fisika dan mekanik bahan bangunan dan pengujian, kayu sebagai bahan bangunan, produk turunan kayu, batu buatan (bata merah dan batako), bahan pengikat (semen, kapur dan aspal), baja dan logam sebagai bahan bangunan, agregat, batu buatan (beton dan produk turunannya), bahanbahan finishing (cat), dan bahan-bahan bangunan modern (baja ringan, kaca dan plastik).

\section{Bahan Bangunan}

Bahan bangunan adalah prioritas utama atau komponen yang sangat penting dalam sebuah bangunan, baik sebagai bahan utama ataupun sebagai bahan penunjang konstruksi. Dengan kata lain, suatu bangunan pada dasarnya berkaitan erat dengan satu atau beberapa bahkan banyak jenis bahan bangunan yang digunakan.

Batu, tanah, logam dan juga kayu merupakan bahan bangunan yang sering digunakan pada awal manusia mengenal alam. Seiring dengan perkembangan zaman yang semakin canggih, pengetahuan tentang bahan bangunan, berbagai formula baru, berbagai jenis bahan bangunan dapat diproduksi dan diolah sendiri oleh manusia seperti satu, kayu, batu bata, besi, beton, kaca, plastik (Tanubrata, 2015). Namun, tak hanya sampai situ saja, para peneliti dan para pemilik industri semakin memberikan ide inovasinya untuk menjawab segala kebutuhan masyarakat yang sangat beragam agar dapat menggunakan bahan bangunan yang lebih efektif, efisien, mudah ditemukan dan dengan keunggulannya dari masingmasing bahan.

Untuk struktur gedung, bahan bangunan biasanya digunakan adalah kayu, beton, dan baja. Saat ini di berbagai proyek pembangunan atau proyek perumahan menggunakan beton ringan, baja ringan, komposit dan lain sebagainya yang digunakan sebagai bahan pengganti kayu. Tak hanya itu, bahan bangunan yang terbaru dan inovatif untuk industri proyek adalah wood concrete dan carbon concrete.

Berdasarkan pemaparan diatas, dapat disimpulkan bahwa paradigma bahan bangunan dari zaman ke zaman mulai mengalami perubahan. Beberapa bahan bangunan terbaru dan modern mulai diciptakan seefisien, dan efektif dengan maksud memenuhi kebutuhan akan hunian dan proyek-proyek pembangunan yang menjadi pusat kehidupan. Pada abad 21 ini, bahan bangunan dibuat dengan berbagai macam kualifikasi dan keunggulan masingmasing seperti bahan bangunan berbahan sintesis sudah mulai dapat diproduksi. Dengan berbagai macam bahan bangunan yang semakin berkembang, maka bangunan dalam bentuk apapun dapat mudah terwujudkan.

\section{Dunia Usaha/ Dunia Industri (DU/DI)}

Menurut Soepraptono, Jalinus, \& Rizal (2019), dunia usaha/idustri merupakan mitra milik pemerintah dan masyarakat yang memiliki peranan sangat penting dalam menunjang keberhasilan dalam dunia pendidikan. Peran dunia usaha/industri dalam pendidikan dapat meningkatkan motif para mahasiswa dalam memasuki dunia kerja. Bentuk dukungan yang diberikan oleh dunia usaha/industri dalam proses pendidikan yaitu: a) memberikan masukan dalam mengembangkan kurikulum dan bahan ajar sesuai dengan tuntutan perkembangan teknologi; b) sebagai penyelenggara magang/praktik kerja mahasiswa; c) sebagai pelaksana Uji Kompetensi mahasiswa/evaluasi dalam belajar.

\section{Metode Penelitian}

Metode penelitian ini menggunakan metode penelitian literature review/tinjauan pustaka. Tinjaun pustaka diperoleh melalui berbagai dokumen atau jurnal penelitian terdahulu yang mendukung penelitian ini untuk dijadikan referensi dalam mencari data. Pengambilan data dilakukan dengan menggunakan atau mengambil sebagian atau seluruhnya dari sekumpulan data yang 
telah dicatat dan semua data yang didapatkan, kemudian akan dikompulasi, dianalisis, dan disimpulkan sehingga didapatkan kesimpulan mengenai studi literatur (Melfianora, 2017).

\section{Hasil Penelitian dan Pembahasan}

\section{Inovasi Bahan Bangunan Konstruksi}

Setelah dilakukan pengumpulan data melalui metode tinjauan pustaka yang diperoleh dari dokumen atau jurnal penelitian terdahulu sebagai referensi, menunjukkan bahwa, perkembangan pembangunan infrastruktur membawa dampak dan pengaruh besar terhadap perkembangan bahan bangunan saat ini. Berbagai inovasi bahan bangunan mulai diciptakan dan dikembangkan dalam memenuhi kebutuhan pembangunan dengan waktu dan mutu yang baik, efisien dan efektif (Hendriyani, Marini \& Putri, 2018). Menurut Putra \& Adi, (2018), penggunaan dari material-material yang inovatif memiliki dampak yang unggul, yaitu waktu pelaksanaan yang lebih efisien, metode pelaksanaan menjadi lebih mudah, mengurangi jumlah sampah, memiliki sifat berkelanjutan karena material inovatif berasal dari bahan yang ramah lingkungan dan beban atau bobot yang diterima struktur dari material bangunan lebih ringan.

Beberapa contoh material-material inovatif yang digunakan untuk bangunan antara lain sebagai berikut:

\section{Baja Ringan}

Baja ringan merupakan merupakan baja dengan kualitas tinggi, memiliki sifat ringan dan tipis, namun kekuatannya tidak kalah dibandingkan dengan baja konvensional. (Pangaribuan, 2014).

Baja ringan berbahan dasar carbon $(1.70 \%)$, manganese $(1.65 \%)$, silicon $(0.60 \%)$ dan coper (0.605). Carbon manganese pada baja ringan merupakan bahan pokok yang meninggikan tegangan (strength) dari baja murni. Baja ringan merupakan baja high tensile G-550 dengan standar bahan ASTM A792, JIS G3302, SGC 570 (Purwanto, 2017).

Baja ringan sebagai bahan bangunan yang inovatif digunakan sebagai kerangka bagian utama maupun atap, menggantikan material kayu. Menurut isu mengenai illegal logging akibat adanya penebangan kayu hutan yang tidak terkontrol, sehingga menempatkan material kayu sebagai material yang mulai berkurang, menjadikan baja ringan sebagai solusi utama dalam mengurangi punahnya material kayu (Imran, 2019).

Penerapan baja ringan di Indonesia, merupakan hal yang belum lama. Masyarakat Indonesia belum begitu mengenali material baja ringan. Hal ini mengakibatkan banyaknya masyarakat yang masih enggan menggunakan baja ringan sebagai bahan bangunan pengganti kayu, padahal baja ringan sangat cocok digunakan di wilayah Indonesia yang notabenenya adalah wilayah yang rawan terjadinya gempa.

Adapun kelebihan dari baja ringan menurut Duppa (2016), yaitu : 1) Baja ringan merupakan material anti rayap. Berbeda dengan material kayu, kualitas kayu yang sering digunakan pada bangunan adalah kelas III, bahkan kebawah, dimana artinya kualitas kayu dinilai kurang baik. Penggunaan material kayu dengan kelas tinggi sudah sangat jarang digunakan pada penyedia, karena jumlahnya yang semakin terbatas. Oleh karena itu, pemilihan baja ringan sebagai material merupakan pilihan yang baik apabila rangka yang dimiliki agar dapat awet atau bertahan lama; 2) Baja ringan dapat mempercepat pelaksanaan pekeraan. Hal ini dikarenakan diproduksi dengan keadaan siap pasang yang tentunya akan mempercepat durasi dari suatu bangunan; 3) Struktur baja ringan memiliki bobot yang lebih ringan, hal ini dapat mempermudah pekerjaan; 4) Baja ringan lebih mengemat biaya. Dari beberapa hasil kajian, rumah type 42 yang dibangun dengan baja ringan dapat mengemat biaya hingga 31juta rupiah; 5) Rangka baja ringan

Relevansi mata... - 187 Ayunda, dkk. 
memiliki struktur yang dapat menyesuaikan dengan keadaan geografis wilayah, dan 6) Baja ringan merupakan solusi inovatif yang dapat menjaga lingkungan.

Kekurangan dari material baja ringan antara lain: 1) Rangka atap dengan baja ringan akan terlihat kurang menarik apabila tidak diberi plafond; 2) Apabila terjadi kesalahan pada perhitungan bagian struktur, maka akan mempengaruhi bagian yang lainnya; 3) Rangka atap dengan baja ringan tidak sefleksibel material kayu yang dapat mudah untuk dibentuk.

Untuk dapat menggunakan baja ringan sebagai material struktur, maka berbagai pertimbangan harus dilakukan guna mencegah hal-hal yang tidak diinginkan. Hal-hal yang dapat dipertimbangakan antara lain adalah material baja yang digunakan harus kuat sesuai dengan perhitungan struktur dan bentuk profil yang digunakan, menghindari jatuhan adukan semen pada saat melakukan pekerjaan plesteran karena dapat mengakibatkan kerusakan lapisan (coating) material baja yang berfungsi sebagai pelindung material dari korosi. Menurut Prowanto (2017) coating untuk baja ringan yaitu galvanized, galvalume, atau disebut dengan zincalume dan ZAM (zink, alumunium dan magnesium).

\section{Bata Ringan}

Bata ringan atau yang biasa disebut dengan blok beton ringan merupakan beton ringan yang diproduksi dengan teknologi proses terbaru serta terbuat dari bahan dasar yang berkualitas. Bata ringan biasanya digunakan sebagai dinding struktur pada bangunan dan panel pada lantai, sesuai dengan jenis dan ukuran dari blok beton yang dipakai (Hendriyani, Marini \& Putri, 2018).

Bata ringan dimanfaatkan sebagai material utama baik sebagai konstruksi maupun sebagai pembentuk elemen struktural menggantikan penggunaan batu bata. Hal ini menjadi kelebihan tersendiri, seperti yang telah diketahui umumnya batu bata dibuat dengan bahan dasar tanah lempung. Tanah lempung diperoleh dengan cara mengekploitasi sumber daya alam. Adanya eksploitasi tersebut mengakibatkan timbulnya kerusakan pada struktur tanah bekas penambangan. Adanya inovasi pada batu bata dapat mengurangi kegiatan yang dapat merusak alam (Ardinal, Wirni \& Haryari, 2020).

Bata ringan dibuat secara komposit, dengan menambahkan subtitusi lainnya. Bahan subtitusi yang dapat digunakan untuk membuat bata ringan sangat banyak sekali macamnya. Beberapa contoh materialmaterial inovatif bata ringan untuk bangunan adalah timbercrete yaitu pembuatan bata dengan menggunakan serbuk kayu sebagai agregat halus, ashcrete yaitu bata yang dibuat dengan menggunakan abu terbang (pembakaran batu bara) sebagai pengganti semen, hempercrete yaitu bata ringan yang dibuat dari serat tanaman hemp yang dicampur dengan kapur. Hempcrete ini sangat mirip dengan beton, namun kuat dan ringan, dan aeration lighweight concrete atau biasa disebut dengan beton aeresi, yaitu dengan menambahkan gelembung udara pada mortar yang hasilnya akan mempengaruhi berat beton (Putra \& Adi, 2018).

Pada penelitian yang dilakukan oleh Widyawati \& Haqqi (2020), bata ringan dibuat dengan memanfaatkan serat sisal sebagai penguat dan limbah plastik pet untuk menggantikan agregat kasar sebagai campurannya, dengan hasil memberikan pengaruh yang baik untuk kekuatan bata sehingga tidak mudah pecah. Pada penelitian yang dilakukan oleh Ardinal, Wirni \& Haryati (2020), bata ringan dibuat dengan menggunakan tongkol jagung sebagai bahan pembuatan bata komposit dengan hasil, bata komposit tersebut memiliki kualitas yang masih memenuhi standar SNI, dan masih banyak lagi contoh dari pemakaian subtitusi bata komposit. Bata komposit merupakan inovasi material bangunan yang ramah lingkungan, karena pembuatannya memanfaatkan limbah sebagai bahan subtitusinya dengan tidak mengurangi kualitas dari batu bata yang 
tertera pada SNI 2847-2013 serta komponen komposit utamanya harus memiliki matrix dan reinforce. Bata ringan yang telah disubtitusikan dengan bahan lain biasanya akan memiliki karakteristik tahan api, kuat terhadap tekanan, memiliki daya serap apir yang rendah, bata kedap suara, dan dapat menyerap panas matahari (Imran, 2019).

Pada penerapannya, bata ringan memiliki keunggulan dibandingkan dengan memakai bahan lainnya, yaitu: 1) Bata ringan memiliki ukuran yang akurat, dimana dengan ukuran tersebut dapat memudahkan pelaksanaan pekerjaan pemotongan; 2) Bata ringan memiliki kuat tekan yang tinggi dan memiliki bobot yang ringan; 3) Bata ringan merupakan isolasi panas dan suara yang baik; 4) Bata ringan mudah dibentuk dan di kerjakan; 5) Bata ringan mempercepat pengerjaan pada kontruksi karena memiliki bobot yang ringan dan kuat, sehingga dapat mempercepat proses pengerjaan; dan 6) Bata ringan tidak beracun, dan tidak dapat dijadikan tempat tinggal bagi serangga (Hendriyani, Marini \& Putri, 2018).

Dalam pemasangannya, bata ringan tidak dapat menggunakan semen, karena bata ringan tidak dapat bersenyawa baik dengan semen. Berikut beberapa produk mortar yang dapat digunakan untuk memasang bata ringan seperti prime mortar, drymix, mortar utama dan lain-lain.

Dari penjabaran mengenai material inovatif tersebut, dapat dilihat bahwa inovasi di industri konstruksi terus mengalami perkembangan terutama dalam hal perkembangan material konstruksi. Hal inilah yang menjadi tujuan utama dalam mengembangkan kompetensi mahasiswa teknik sipil terkait perkembangan material di dunia konstruksi (Nugroho, dkk, 2019).

\section{Relevansi Mata Kuliah Ilmu Bahan Bangunan}

Pesatnya perkembangan industri bahan bangunan di Indonesia, tentunya akan membuat mahasiswa Teknik Sipil dituntut untuk up to date terkait perkembangan tersebut, karna nantinya para mahasiswa akan semakin saling berkompetisi dan berlomba-lomba untuk menjadi mahasiswa yang berkembang dan inovatif.

Keterkaitan antara perguruan tinggi dengan dunia industri konstruksi menjadi hal yang sangat penting, dimana perguruan tinggi diharapkan dapat membekali mahasiswanya dengan keterampilan yang sesuai untuk mengisi dunia lapangan kerja (Arifin \& Amri, 2017). Program studi yang mempengaruhi kompetensi mahasiswa terkait perkembangan bahan bangunan di dunia industri kontruksi adalah Prodi Teknik Sipil, dimana terdapat Mata Kuliah Ilmu Bahan Bangunan, yang membahas bahan bangunan dan diharapkan dapat menunjang pembelajaran terkait dengan industri bahan bangunan konstruksi yang telah berkembang.

Dari beberapa kaijan analisis, menurut penelitian yang dilakukan oleh Eki Julistiana (2018) menemukan bahwa relevansi materi pelajaran mengenai bahan bangunan hasilnya sangat relevan, namun pada materi finishing bangunan hasilnya kurang relevan dengan kebutuhan. Selain itu, menurut penelitian Suwarsono dan Suharto HP (2013), menemukan bahwa relevansi pada mata pelajaran ilmu bahan bangunan termasuk dalam kategori sangat relevan dengan kebutuhan industri. Namun, pada mata pelajaran tersebut masih belum membahas mengenai ilmu bahan bangunan yang terbaru dan mulai digunakan di dunia industri pembangunan gedung. Hal ini disebakan karena kurang relevannya kurikulum dengan kompetensi yang dibutuhkan di dunia kerja.

Dalam usahan menyempurnakan kompetensi mahasiswa terkait bahan bangunan yang berkembang dan inovatif di dunia industri, para peneliti dan beberapa pendapat setuju bahwa setiap mata kuliah dibutuhkan relevansi dengan kebutuhan pada pasar kerja. Kegiatan relevansi sangat baik dilakukan pada setiap kurikulum mata kuliah, khususnya mata kuliah Ilmu Bahan Bangunan di perguruan tinggi dengan menyesuaikan kebutuhan dunia industri 
(Soepraptono, Jalinus, \& Rizal, 2019). Semakin baik perguruan tinggi dalam melakukan proses pendidikan, maka akan menghasilkan lulusan yang semakin berkualitas. Dengan melakukan relevansi, akan mempertajam kompetensi mahasiswa baik dalam hal kualitas maupun kuantitas yang nantinya akan bekerja dan berkonstribusi didalamya.

\section{Simpulan}

Berdasarkan hasil dari pengumpulan data literatur, maka dapat disimpulkan bahwa relevansi mata kuliah sangat dibutuhkan untuk mengembangkan komptensi mahasiswa sesuai dengan kebutuhan industri. Relevansi dilakukan dengan berorientasi pada pasar kerja dengan ide-ide dalam menjalankan pendidikan, sehingga dengan adanya pendidikan dapat melatih mahasiswa sebelum terjun langsung menghadapi dunia kerja. Ditinjau dari industri bahan bangunan yang berkembang, membuat mata kuliah Ilmu Bahan Bangunan sangat baik apabila melakukan relevansi sebagai bentuk pendekatan perencanaan pendidikan dalam menghasilkan sumber daya manusia yang mampu bekerja secara profesional dan up to date terkait adanya inovasi bahan bangunan terbaru di dunia industri konstruksi seperti baja ringan, bata ringan dan lain sebagainya.

\section{Daftar Pustaka}

Ardinal., Wirni, R., \& Haryati, N.A (2020). Pengaruh Penambahan Limbah Tongkol Jagung untuk Pembuatan Batu Bata Ringan. Jurnal Litbang Industri, 10(1), 3945. https://doi.org/10.24960/jli.v10i 1.6180.39-45.

Arifin, AN., Amri, FR. (2017). Relevansi Kompetensi Teknik Gambar Manufaktur Di SMK Muhammadiyah 2 Jatinom Terhadap Kebutuhan Industri. Jurnal Dinamika Vokasional Teknik Mesin, 2(2), 105110. https://doi.org/10.21831/dinam ika.v2i2.15997.
Duppa, H. (2016). Efektifitas Penggunaan Baja Ringan untuk Struktur Rangka Atap Gedung. Jurnal Ilmiah Teknik TEKSTUR KOTA, 7(2), 7988. https://doi.org/10.31227/osf.io/ sx5ag.

Hamdan, Suherman, A., \& Ariyanto. (2015). Relevansi Materi Mata Kuliah Gambar Teknik Dan Materi Mata Pelajaran Gambar Teknik Dengan Materi Standar Uji Kompetensi. Journal of Mechanical Engineering Education, 2(1), 4858. HTTPS://DOI.ORG/10.17509/ JMEE.V2I1.1153.

Hasbiallah. (2016). Relevansi Materi Hadis Pada Jurusan PAI Dengan Bahan Ajar Quran Hadis Pada Madrasah Tsanawiyah. Islamic Religion Teaching and Learning Journal, 1(1), 7184. https://doi.org/10.15575/ath.v1i 1.2436.

Hendriyani, I., Marini, A., \& Putri, N.I. (2018). Analisis SWOT Pemilihan Material Dinding Bata Merah dan Bata Ringan di Penajam Paser Utara. Jurnal Teknik Sipil, 2(1), 2232. https://doi.org/10.35334/be.v2i1 .609 .

Imran, M. (2019). Material Konstruksi Ramah Lingkungan Dengan Penerapan Teknologi Tepat Guna. Jurnal Peradaban Sains, Rekayasa dan Teknologi, 6(2), 146157. https://doi.org/10.37971/radial. v6i2.173.

Julistiana, E., Murtinigraha, R.E., \& Bachtiar, G. (2018). Relevansi Materi Ajar Di Prodi PTB FT UNJ Dengan Materi Ajar Di SMK Program Keahlian Teknik Bangunan. Jurnal Pendidikan Teknik Sipil, 7(1), 18. https://doi.org/10.21009/pensil.7. 1.1.

Melfianora. (2017). Penulisan Karya Tulis Ilmiah Dengan Studi Literatur. Studi Literatur, 1-3. 
Novianto, A., Suherman, A., \& Ariyanto. (2015). Relevansi Materi Mata Kuliah Keahlian Otomotif Dengan Materi Mata Pelajaran Kompetensi Keahlian Teknik Kendaraan Ringan Terhadap Materi Uji Kompetensi Keahlian Standar BSNP. Journal of Mechanical Engineering Education, 2(1), 1222. https://doi.org/10.17509/jmee.v 2i1.1149.

Nugroho, et al. (2019). Healox Brick: Inovasi Batako Pendukung Konsep Prefebricate Building Yang Ringan, Ekonomis dan Ramah Lingkungan. Jurnal Proyek Teknik Sipil, 2(1), 2530. https://doi.org/10.14710/potensi .2019 .4799 .

Pangaribuan, M.R. (2014). Baja Ringan Sebagai Pengganti Kayu Dalam Pebuatan Rangka Atap Bangunan Rumah Masyarakat. Jurnal Teknik Sipil dan Lingkungan, 2(4), 648-655.

Purwanto, H. (2017). Analisis Efisiensi Konstruksi Rangka Atap Baja Ringan. Jurnal Deformasi, 2(1), 2636. https://doi.org/10.31851/deform asi.v2i1.2817.

Putra, K.H.N \& Adi, T.J.W. (2018). Perbandingan Biaya Material dengan Memodifikasi Struktur Bangunan Menggunakan Beton Ringan pada Proyek Gedung Asrama Berlantai 5 LPMP Sumatera Barat. Jurnal Teknik ITS, $\quad 7(2), \quad 121-126$ https://doi.org/10.12962/j23373539. v7i2.36178.
Soepraptono., Jalinus, N., \& Rizal, F. (2019). Relevansi Kompetensi Mata Pelajaran Produktif dengan Kompetensi Industri Program Keahlian Teknik Kendaraan Ringan. Jurnal Pendidikan Teknologi Kejuruan, 2(3), 75 79. https://doi.org/10.24036/jptk.v2i 3.3623.

Suwarsono \& Suharto, HP. (2013). Relevansi Kurikulum Teknik Gambar Bangunan SMKN 3 Yogyakarta dengan Kebutuhan Dunia Industri. Jurnal Pendidikan Vokasi, 3(3), 359372. https://doi.org/10.21831/jpv.v3 i3.1849.

Tanubrata, M. (2019). Bahan-Bahan Konstruksi Dalam Konteks Teknik Sipil. Jurnal Teknik Sipil, 11(2), 132154.

https:doi.org/10.28932/its.v11i2.1407

UNJ. (2017). Buku Pedoman Akademik Fakultas Teknik. Jakarta: Universitas Negeri Jakarta.

Widyawati, F., \& Haqqi, T.A. (2020). Pemanfaatan Serat Sisal (agave sisalana L.) dan Limbah Plastik Pet untuk Pembuatan Bata Ringan CLC (Cellular Lightweight Concrete). Jurnal Tambora, 4(1), 21 25. https://doi.org/10.36761/jt.v4i1. $\underline{566 .}$ 